\title{
Burden of phenylketonuria in Latin American patients: A systematic review and meta-analysis of observational studies
}

\section{André Luiz Santos Pessoa}

UECE: Universidade Estadual do Ceara

\section{Ana Maria Martins}

UNIFESP: Universidade Federal de Sao Paulo

\section{Erlane Ribeiro}

Christus University Centre: Centro Universitario Christus

\section{Norma Specola}

Universidad Nacional de la Plata

\section{Ana Chiesa}

CEDIE: Centro de Investigaciones Endocrinologicas

\section{Daniel Vilela}

Biomarin Pharmaceutical Inc

\section{Elaina Jurecki}

Biomarin Pharmaceutical Inc

\section{Debora Mesojedovas}

Biomarin Pharmaceutical Inc

Ida Schwartz ( $\square$ idadschwartz@gmail.com )

HCPA: Hospital de Clinicas de Porto Alegre https://orcid.org/0000-0002-7933-6687

\section{Research Article}

Keywords: Neurological disease, Attention Deficit Hyperactivity Disorder, Overweight, Phenylketonuria, LATAM

Posted Date: February 23rd, 2022

DOI: https://doi.org/10.21203/rs.3.rs-1363158/v1

License: (c) (1) This work is licensed under a Creative Commons Attribution 4.0 International License.

Read Full License 


\section{Abstract}

Background: Phenylketonuria (PKU) is an inborn error of metabolism caused by a deficiency of the enzyme phenylalanine hydroxylase. If untreated, the complications of PKU lead to significant neucognitive and neuropsychiatric impairments, placing a burden on both the individual's quality of life and on the healthcare system. We conducted a systematic literature review to characterize the impact of PKU on affected individuals and on healthcare resources in Latin American (LATAM) countries.

Methods: Searches of the global medical literature as well as regional and local medical literature up to September 2021. Observational studies on patients with PKU from any LATAM country. Pairs of reviewers independently screened eligible articles, extracted data from included studies, and assessed their risk of bias.

Results: 79 unique studies (47 cross-sectional studies, 18 case series, 12 case reports, and two cohort studies) with a total of 4,090 patients were eligible. Of these studies, 20 had data available evaluating early-diagnosed PKU patients for meta-analysis of burden outcomes. Intellectual disability in the pooled studies was $18 \%$ [95\% Confidence Interval $(\mathrm{Cl}) 0.04$ to $0.38 ; I^{2}=83.7 \%, p=0.0133$; two studies; $n=114$ ]. Motor delay was $15 \%$ [95\% $\mathrm{Cl} 0.04$ to $0.30 ; I^{2}=74.5 \%, p=0.0083$; four studies; $n=132$ ]. Speech deficit was $35 \%$ [95\% $\mathrm{Cl} 0.08$ to $0.68 ; 1^{2}=93.9 \%, p<0.0001$; five studies; $\left.n=162\right]$.

Conclusions: There is currently evidence of high clinical burden in PKU patients in LATAM countries. Recognition that there are many unmet neuropsychological needs and socioeconomic challenges faced in the LATAM countries is the first step in planning cost-effective interventions.

\section{Background}

Phenylketonuria (PKU) is an inborn error of metabolism caused by a deficiency of the enzyme phenylalanine hydroxylase (PAH) which results in elevated levels of phenylalanine (Phe) and reduced levels of tyrosine [1]. The incidence within Latin American (LATAM) countries is estimated at 1 in 23,000 live births [2]. PKU presents a spectrum of severity, and there are plenty of different classifications that have been proposed [2]. Individuals with classical PKU have a complete enzyme deficiency resulting in untreated blood Phe levels $>1,200 \mu \mathrm{mol} / \mathrm{L}$ (average normal Phe level is approximately $60 \mu \mathrm{mol} / \mathrm{L}$ ), which is considered the severe form of this disorder [2]. Patients with untreated blood Phe levels greater than the normal level but less than $600 \mu \mathrm{mol} / \mathrm{L}$ were classified as having mild and moderate forms of hyperphenylalaninemia (HPA) [2].

The treatment for PKU is a lifelong dietary restriction of protein supplemented by a Phe-free amino acid fortified medical food [1], and ongoing monitoring of blood Phe levels to maintain a target range of 120 $\mu \mathrm{mol} / \mathrm{L}$ to $600 \mu \mathrm{mol} / \mathrm{L}$ for patients $\geq 12$ years old, and up to $360 \mu \mathrm{mol} / \mathrm{L}$ for those $<12$ years old [3]. If left untreated, the disease can manifest as significant intellectual impairment, neuropsychiatric disorders, and seizures [4] which place a burden on the individual's quality of life, their families, and on the public 
and private healthcare systems [5]. Even patients diagnosed and treated at an early age face significant challenges related to adherence with the Phe-restricted diet.

Evaluating the unmet needs and burden of PKU on affected individuals is important to determine the impact on the LATAM public and private healthcare system. Recognition that there are many challenges that the patient with PKU faces is the first step in planning for cost-effective intervention scenarios. We therefore conducted a systematic literature review and meta-analysis to better characterize the impact of PKU in LATAM countries on selected patient-important outcomes as well as at the economic (socioeconomic, healthcare utilization) level.

\section{Material And Methods}

Our review followed recommendations for systematic reviews and meta-analyses (PRISMA) [6] of observational studies in epidemiology (MOOSE) [7]. This systematic review has been registered in the PROSPERO (International Prospective Register of Systematic Reviews) database under the number CRD42020211417.

\section{Eligibility criteria}

We included any epidemiological observational study (ie, cohort, case-control, nested case-control, crosssectional studies, case series, case reports, surveys) on patients with PKU or phenylalanine hydroxylase deficiency (PAH), regardless of disease severity, including classical, moderate, and mild forms of this disorder, from any LATAM country regardless of whether they reported on any of the pre-defined patientimportant outcomes and/or economic burden outcomes as defined below. We also included studies on caregivers of PKU patients.

Studies that only reported disease prevalence or incidence as well as non-human studies and subjective reports of clinical or observational studies such as letters, editorials and commentaries were excluded.

Pre-defined patient-important outcomes of interest included:

- Neurological, neurocognitive and neuropsychiatric impairments: intellectual disability, mental disorders, autism spectrum disorder, motor deficits, speech deficits and language delay, tremor, Attention Deficit Hyperactivity Disorder (ADHD) and hyperactivity, mood, depression, anxiety, phobias, irritability and/or aggressiveness, frustration, social isolation;

- Executive function deficit: working memory, sustained attention, inhibitory control, processing speed impairments, impairment in visuomotor coordination;

- Other comorbidities such as overweight, osteopenia, osteoporosis, skin problems, headaches, fatigue and sleeping disorder;

- Quality of life measured by non-validated and validated questionnaires, as defined by the included studies; and 
- Patient adherence to clinical recommendations, including frequency of blood testing (ideally biweekly to monthly with targeted Phe concentrations of $120-360 \mu \mathrm{mol} / \mathrm{L}$ as recommended by the American College of Medical Genetics and Genomics (ACMG) guidelines (1)) and 120-600 $\mu \mathrm{mol} / \mathrm{L}$ for those $\geq 12$ years of age by the European guidelines [8] and dietary management including a Pherestricted diet supplemented by Phe-free amino acid fortified medical foods as well as the use of sapropterin dihydrochloride in patients who are responsive to this pharmacological treatment.

Symptoms of being late-treated for the disease, such as seizures, microcephaly, generalized rash, and peculiar-smelling urine, were not investigated as patient-important outcomes for the purposes of this review.

Pre-defined economic outcomes of interest included:

- Socioeconomic impact (eg, school / education level, work experience and productivity, marital status, personal independence, living situation, employment, social status);

- Impact of PKU on caregiver health-related quality of life; and

- Impact of PKU on the healthcare system (eg, direct and/or indirect costs, treatment costs, health care resource use, cost of comedications, hospitalizations).

\section{Data source and searches}

Using Medical Subject Headings (MeSH) based on the terms "phenylketonuria" and "phenylalanine" (Supplementary table 1) we performed the search in the global medical literature using Medical Literature Analysis and Retrieval System Online (MEDLINE, via PubMed, from 1946 to September 2021), Excerpta Medica Database (EMBASE, via Elsevier, from 1974 to September 2021), and Web of Science (to September 2021).

In the regional and local medical literature, both Spanish and English terms were used to search in Latin American and Caribbean Health Sciences Literature (LILACS, 1982 to September 2021), Scientific Electronic Library Online (SciELO, 1997 to September 2021), SciVerse Scopus via Elsevier (to September 2021), the Spanish Bibliographic Index of the Health Sciences (IBECS, 1983 to September 2021), National Bibliography in Health Sciences Argentina (BINACIS, to September 2021), Caribbean Health Sciences Literature (MedCarib, to September 2021), National Medical Sciences Information Center of Cuba (CUMED, to September 2021), Brazilian Bibliography of Dentistry (BBO, to September 2021), Health Information Locator (LIS, to September 2021), Regional Database of Health Technology Assessment Reports of the Americas (BRISA/RedTESA, to September 2021), Nursing Database (BDENF, to September 2021), Index Psychology (IndexPsi, to September 2021), and the WHO Institutional Repository for Information Sharing (WHO IRIS, to September 2021). The date the search was conducted was September 24,2021 and no starting date restrictions, or language restrisctions, were imposed. The search strategy was adapted for each database to achieve more specificity and sensitivity. Duplicate records across databases were removed. 
We searched the gray literature including the Brazilian Digital Library of Theses and Dissertations (BDTD). In addition, reference lists of relevant primary studies were hand searched and experts in the field were contacted to obtain additional unpublished data where feasible.

\section{Selection of studies}

Reviewers independently screened all titles and abstracts identified by the literature search using online software Covidence (https://www.covidence.org), obtained full-text articles of all potentially relevant studies, and evaluated them against the eligibility criteria. Reviewers resolved disagreement by discussion or, if necessary, with third party adjudication. We also considered studies reported only as abstracts. We recorded the selection process and documented via a PRISMA (Preferred Reporting Items for Systematic Reviews and Meta-Analyses) flow diagram (Fig. 1).

\section{Data extraction}

Reviewers independently extracted the following data using a pre-standardized data extraction form: (a) first author and year of publication; (b) country; (c) study design; (d) scenario; (e) age and gender; ( $f$ ) diagnoses (classic or mild PKU, HPA); however defined per the authors of the included studies; (g) eligibility criteria; $(\mathrm{h})$ early diagnosis and early start of treatment (we considered that late diagnosed refers to children diagnosed between the ages of 3 months to 7 years ( $\geq 3$ months to $<7$ years); untreated PKU refers to patients untreated by 7 years of age and over [3]); and (i) patient-important and economic outcomes, if available. We avoided double-counting of patients where there were multiple publications of the same population. If there was more than one published report of the same group of patients, the articles were analyzed to verify whether or not they reported different outcomes. If they presented the same outcomes, data was extracted from the most recent article.

When the study did not specify whether the disease was classic, mild, or hyperphenylalaninaemia (HPA), we considered them as PKU.

\section{Risk of bias assessment}

We evaluated risk of bias assessment only for those studies that reported patient-important outcomes (n $=30$ cross-sectional studies; $n=17$ case series; no cohort or case-control studies assessed these outcomes).

For cross-sectional studies, we assessed risk of bias with the AXIS tool [9], though we excluded some domains not applicable to our review. For case series, we used the Joanna Briggs Institute (JBI) critical appraisal checklist [10]. Response options for both tools were modified to "definitely yes" (low risk of bias), "partially yes" (not all information needed available), "unclear" (no information to judge), and "definitely no" (high risk of bias), as we believe that this categorization is more reliable.

For cohort and case-control studies, we planned to assess risk of bias with a modified version of the Ottawa-Newcastle instrument [11] that includes confidence in assessment of exposure and outcome; 
however, there was no included study classified as either a cohort or case-control study assessing patientimportant outcomes in order we could assess their risk of bias.

\section{Data synthesis and statistical analysis}

We performed a systematic review of studies with pooled analysis of proportions [12, 13], using the method of Stuart-Ord (inverse double arcsine square root) with their respective $95 \%$ confidence intervals (CI). Only case series and cross-sectional studies were considered for quantitative analysis; case reports were excluded. To avoid bias related to the effect of delayed implementation of dietary management in late treated patients, only early-diagnosed patients (ie, diagnosed within first three months of life) were included. Studies that did not report whether the treatment was implemented at an early or late age were excluded from the meta-analysis as well as those that did not separate data for the early- or latediagnosed patients.

Since we expected that there were both clinical and methodological differences among the included studies, a random-effects model [14] was used to perform the pooled analysis of proportions [12, 13]. The meta-analysis was performed with the StatsDirect software, version 2.8.0. (StatsDirect Ltd, Altrincham, Cheshire, UK).

\section{Subgroup and sensitivity analyses}

There were several protocol stated pre-planned subgroup analyses provided there was a minimum of two studies in each category: (1) start of treatment (early diagnosed was considered up to three months of life, inclusively; (2) patients maintaining blood Phe in targeted range versus those not able to do so; (3) PKU impact evaluated by Patient-Reported Outcomes (PROs) and validated clinical tools (eg, questionnairies, scales) versus health care and parents/caregivers perception; (4) children versus adults; (5) countries with newborn screening available versus countries without; and (6) per LATAM countries (eg, Brazil versus Argentina). However due to insufficient number of studies, only one subgroup analysis by country could be conducted. Further pre-planned sensitivity analysis to explore causes of heterogeneity of the results, separating studies according to study designs (eg, cross-sectional versus case series) were not conducted due to insufficient number of studies to allow for these assessments.

\section{Heterogeneity assessment and publication bias}

We investigated heterogeneity using the chi-square test and the $\mathrm{I}^{2}$ statistic [15]. An $\mathrm{I}^{2}$ value of $0-40 \%, 30-$ $60 \%, 50-90 \%$ or $75-100 \%$ was interpreted as not important, moderate, substantial, or considerable heterogeneity, respectively, and significance will be assumed when $\mathrm{I}^{2}$ was $\geq 50 \%$ with a $\mathrm{P}<0.1$.

There was an insufficient number of studies (at least 10 or more) to allow for assessment of publication bias through visual inspection of funnel plots. Review Manager (RevMan) provided the software for all analyses (version 5.3; Nordic Cochrane Centre, Cochrane) [16].

\section{Results}




\section{Study selection}

Our initial searches identified 3,917 citations ( $n=3,854$ from electronic searches; $n=63$ identified through the gray literature). After removing duplicates from different databases, 3,081 potentially relevant articles were further assessed using title and abstract review. A total of 202 articles were identified for full text assessment. After screening the full texts, we included 79 studies with 11 further publications (ie, multiple publications of the same set of patients) (47 cross-sectional studies, 18 case series, 12 case reports, and two retrospective cohort studies) with a total of 4,090 patients [17-106]. The reasons for exclusion are listed in the PRISMA flow diagram (Fig. 1). When studies were presented in more than one publication, all applicable references were included.

Six of the included studies were published only as an abstract $[18,19,37,57,58,67,104]$, nine studies as a thesis $[33,43,49,65,70,73,88,93,96]$, and the majority $(n=57)$ were published as full-text in peerreviewed journals $[17,20-23,28-30,34-36,38-42,44-48,50-56,59-64,66,68,69,71,72,74-87,94$, $95,97-99,102,103]$. Seven further studies $[24,26,31,89,91,100,105]$ were published initially as a thesis followed by a full-text publication $[25,27,32,90,92,101,106]$. When information regarding risk of bias or other aspects related to study criteria were unavailable in the methods, we attempted to contact study authors for additional information.

\section{Study characteristics}

Sixty-four of the 79 included studies reported at least one patient-important outcome at individual or population level, and they are displayed in Table 1 for study characteristics. Regarding study design, 18 were case series [21, 22, 36, 38, 39, 42, 49, 53, 54, 59, 61, 65, 80, 84, 94, 97, 99, 104], 47 cross-sectional studies $[18-20,24-35,40,43-45,52,55,57,58,60,62,63,66,67,70-72,74,77-79,88-93,95,100-$ $102,105,106], 13$ case reports $[23,41,46,50,64,68,75,76,81,86,87,103,104]$, and two cohort studies $[56,85]$.

Forty of the included studies were conducted in Brazil [18, 20, 24-27, 31-33, 40, 42, 43, 49, 50, 52, 55, 59, $60,62,63,65-68,70-72,78-80,86-95,97,99-102,105,106]$, seven in Argentina [19, 22, 23, 28-30, 34, $44,45,57,58]$, five in Chile $[35,36,38,39,77]$, three each in Colombia $[46,53,103]$ and Mexico $[54,76,84]$, two each in Ecuador [41, 75], Venezuela [61, 64] and Uruguay [21, 81], and one in Cuba [74]. One study [104] was a multicenter conducted in Ecuador, Bolivia, and Paraguay. The case series and cross-sectional studies sample size ranged from two [21] to 420 patients [44, 45]. Patients' ages ranged from a mean of 3.11 [35] to 19.3 [102] years old (Table 1).

The type of patient-important outcomes most frequently reported among the cross-sectional and case series studies were neurological, neurocognitive and neuropsychiatric impairments $(\mathrm{n}=33$ studies, 50.8\%) $[20-22,24,25,31,32,34-36,38-40,42,43,49,52-54,60-62,66,70,72,74,77,80,84,89-93,97,104-$ $106]$, followed by overweight $(n=11,16.9 \%)[26,27,36,55,65,74,77,78,88,95,99,102]$, patient adherence to clinical recommendations $(n=10,15.4 \%)[22,49,63,71,72,79,94,100,101,104-106]$, executive function deficit $(n=6,92.3 \%)[43,59-62,70]$, socioeconomic impact $(n=7,10.8 \%)[53,60,66$, 
$74,79,97,105,106]$, skin problems $(n=4,6.2 \%)[18,53,54,74]$, osteopenia $(n=5,7.7 \%)[57,58,65,67$, $74,89,90]$, followed by impact of PKU on caregiver health-related quality of life, quality of life and sleeping disorders $(n=2,3.1 \%)[60,66,72,97]$. The majority of the cross-sectional, case series, and case report studies $(83.1 \%, n=64)$ reported only on patient-important outcomes at an individual level (Table 1$)$.

Among the 12 case report studies, the majority $(83.3 \%, n=10)$ assessed neurological, neurocognitive and neuropsychiatric impairments $[41,46,64,68,75,76,81,86,87,103]$, executive function deficit $[23,41,68$, $75,81]$, skin problems $[41,46,64,68]$, and patient adherence to clinical recommendations $[64,68,76]$. Six case report studies $[46,50,68,75,86,87]$ evaluated other outcomes such as vomiting $[46,68,86]$, weightheight deficit [68], abdominal distention [75], persistent respiratory acidosis [75], gastroesophageal reflux [86], bronchitis [86], megaloblastic anemia [87], and maternal phenylketonuria [50] (Table 1).

Supplementary table 2 describes the 15 studies evaluating other patient-important or economic burden outcomes than those pre-specified for this review; all of these, except for three studies [19, 44, 45, 47], reported that patients received a Phe-restricted diet and/or a Phe-free amino acid fortified medical food. Six studies out of 15 did not report whether patients were receiving treatment $[19,44,45,51,69,73]$.

Supplementary table 3 provides additional details around the specific pre-specified patient-important or economic burden outcomes reported among the 12 case report studies. Five out of the 12 studies reported psychosocial outcomes (ie, severe mental retardation and autism, irritability, aggressiveness and intellectual deterioration) $[41,46,68,81,103]$; four on physical outcomes (ie, psychomotor retardation) $[41,68,81,103]$; one study reported on other outcomes (ie, maternal phenylketonuria) [50]; and two studies reported socioeconomic results (ie, delay in school performance, poor socialization, and withdrawal from formal schooling) $[68,103]$.

\section{Risk of bias assesment}

Figure 2 and Supplementary tables 4 and 5 describe the risk of bias assessment. Overall, the included studies presented a low risk of bias in the majority of the domains. In the cross-sectional studies (Fig. 2, panel A), at least one of the following domains of sample size, statistical significance, statistics methods, or demographic data were rated as "high risk of bias" in five studies $(12.8 \%)[18,34,35,40,79]$. In the case series studies (Fig. 2, panel B), three domains (ie, clear description of both patient's history and postintervention clinical condition, and description of a takeaway lesson) were rated as "high risk of bias" in three studies $(25.0 \%)[21,59,97]$.

\section{Meta-analysis results}

The results were pooled from case series and cross-sectional studies that reported data only on earlydiagnosed patients to avoid bias related to the effects of delayed implementation of dietary management in late-diagnosed patients. Studies that did not provide quantitative data on outcome of interest in papers were also excluded from analysis as well as studies that did not report whether the treatment was implemented at an early or late age. Therefore, out of 67 included studies $[17,18,20-27,31-33,35-39$, $41-43,46-49,51-56,60-65,67-78,80-94,96-103,105,106], 20$ studies [18, 20, 26, 27, 31, 32, 35, 36, 
$38,39,49,52,54,60,61,63,71,72,89-92,105,106]$ qualified for the quantitative analysis described below. None of the included studies evaluating early-diagnosed PKU patients reported symptoms including headache and fatigue, quality of life, or the impact of PKU on the healthcare system.

\section{Neurological, neurocognitive, and neuropsychiatric impairments}

\section{Attention Deficit Hyperactivity Disorder (ADHD) and hyperactivity}

The pooled proportion of ADHD and hyperactivity was $40 \%$ [95\% $\mathrm{Cl} 0.21$ to $0.61 ; \mathrm{I}^{2}=89.2 \%, \mathrm{p}<0.0001$ ] from eight studies $[20,35,52,60,61,89,91,92,105,106]$ with a total of 222 patients (Fig. 3, panel A). There was significant statistical heterogeneity in the analyses. We considered plotting hyperactivity along with ADHD; however, when studies provided data on both outcomes, we chose to use data from the latter one as hyperactivity is considered part of the ADHD diagnosis.

\section{Austism}

Only one study [49] evaluating early-diagnosed PKU patients reported on autism. Out of 78 patients, two were diagnosed with autistic behaviour.

\section{Intellectual disability}

The pooled proportion of intellectual disability was $18 \%\left[95 \% \mathrm{Cl} 0.04\right.$ to $0.38 ; \mathrm{I}^{2}=83.7 \%, p=0.0133$ ] from two studies [31, 32, 72] with a total of 114 patients (Fig. 3, panel B). There was significant statistical heterogeneity in the analyses.

\section{Irritability and aggressiveness}

The pooled proportion of irritability and aggressiveness was $44 \%$ [ $95 \% \mathrm{Cl} 0.12$ to $0.80 ; I^{2}=96.2 \%, p<$ $0.0001]$ from five studies $[35,49,60,61,105,106]$ with a total of 200 patients (Fig. 3, panel C). There was significant statistical heterogeneity in the analyses.

\section{Mental disorders}

The pooled proportion of mental disorder was $16 \%$ [ $95 \% \mathrm{Cl} 0.01$ to $\left.0.42 ; \mathrm{I}^{2}=89.7 \%, \mathrm{p}<0.0001\right]$ from three studies $[35,39,105,106]$ with a total of 115 patients (Fig. 3, panel D). A study [39] that reported slight retardation was also considered in this analysis. There was significant statistical heterogeneity in the analyses.

\section{Motor delay}

The pooled proportion of motor delay was $15 \%$ [95\% $\mathrm{Cl} 0.04$ to $0.30 ; \mathrm{I}^{2}=74.5 \%, \mathrm{p}=0.0083$ ] from four studies [38, 49, 52, 91, 92] with a total of 132 patients (Fig. 3, panel E). There was significant statistical 
heterogeneity in the analyses. Any report of motor delay such as low motor development, neuromotor restriction [49], and deficit for gross motor area [91, 92] was considered.

\section{Speech and language deficits}

The pooled proportion of speech and language deficits was $35 \%\left[95 \% \mathrm{Cl} 0.08\right.$ to $0.68 ; I^{2}=93.9 \%, p<$ 0.0001 ] from five studies [35, 49, 52, 61, 91, 92] with a total of 162 patients (Fig. 3, panel F). There was significant statistical heterogeneity in the analyses. Additional reports of speech delay included speech deficits such as "only emits a word" [21], alterations in language [52], and mild to moderate speech disorder [91, 92] were reported.

\section{Other comorbidities}

\section{Obesity}

The pooled proportion of obesity was $12 \%$ [95\% $\mathrm{Cl} 0.09$ to $0.15 ; \mathrm{I}^{2}=0 \%, \mathrm{p}=0.6129$ ] from three studies [26, $27,36,95]$ with a total of 379 patients (Fig. 4, panel A). There was no significant statistical heterogeneity in the analyses.

\section{Overweight}

The pooled proportion of overweight was $11 \%\left[95 \% \mathrm{Cl} 0.07\right.$ to $\left.0.16 ; \mathrm{I}^{2}=47.2 \%, \mathrm{p}=0.1504\right]$ from three studies [26, 27, 36, 95] with a total of 379 patients (Fig. 4, panel B). There was no significant statistical heterogeneity in the analyses.

\section{Osteopenia}

Only one study $[89,90]$ evaluating early-diagnosed PKU patients reported on osteopenia. Out of 31 patients, three were diagnosed with osteopenia.

\section{Skin alterations}

The pooled proportion of skin alterations was $34 \%\left[95 \% \mathrm{Cl} 4.9 \mathrm{E}-3\right.$ to $\left.0.85 ; \mathrm{I}^{2}=85.7 \%, \mathrm{p}=0.0081\right]$ from two studies $[18,54]$ with a total of 40 patients (Fig. 4, panel C). Both included studies reporting lightening of the skin. There was significant statistical heterogeneity in the analyses.

\section{Sleeping disorders}

The pooled proportion of sleeping disorders was $71 \%\left[95 \% \mathrm{Cl} 0.13\right.$ to $\left.0.99 ; I^{2}=86.2 \%, p=0.007\right]$ from two studies $[60,61]$ with a total of 22 patients (Fig. 4, panel D). There was significant statistical heterogeneity in the analyses.

\section{Patient adherence to clinical recommendations after treatment}


The pooled proportion of patient adherence to clinical recommendation was $53 \%\left[95 \% \mathrm{Cl} 0.38\right.$ to $0.67 ; \mathrm{I}^{2}$ $=83.7 \%, p<0.0001]$ from five studies $[49,63,71,72,105,106]$ with a total of 260 patients (Fig. 4, panel E). There was significant statistical heterogeneity in the analyses.

\section{Socioeconomic impact}

The pooled proportion of socioeconomic impact was $37 \%$ [95\% $\mathrm{Cl} 0.07$ to $0.75 ; \mathrm{I}^{2}=88.5 \%, \mathrm{p}=0.0032$ ] from two studies $[60,105,106]$ with a total of 73 patients (Fig. 5, panel A). There was significant statistical heterogeneity in the analyses. The included studies reported the following socioeconomic impact: poor school performance [60], and special education [105, 105].

\section{Impact of phenylketonuria on caregiver health-related quality of life}

The pooled proportion of impact of PKU on caregiver health-related quality of life (ie, did not acquire toilet training $[21,97]$ ) was $42 \%$ [95\% $\mathrm{Cl} 0.09$ to $\left.0.80 ; \mathrm{I}^{2}=0 \%, \mathrm{p}=0.7519\right]$ from two studies $[21,97]$ with a total of five patients (Fig. 5, panel B). There was no significant statistical heterogeneity in the analyses.

\section{Descriptive analysis of single studies reporting the outcomes of interest}

Four studies $[59,60,62,70]$ reported executive function outcomes with $41 \%$ being classified as below average in the assessment of receptive vocabulary using the Peabody Image Vocabulary Test [60]. Malloy-Diniz et al. [62] reported that PKU children with high blood Phe levels (ie, mean Phe levels between 360 and $600 \mu \mathrm{mol} / \mathrm{L}$ ) performed significantly worse than both the PKU children with low blood Phe levels and the control children on tasks that assess executive functioning. Morão et al. [70] found that the patients also showed a loss in the score of the Children Gambling Task. Lamônica et al. [59] reported that out of 10 patients, two of them presented outside the normality standards in the development scales. The skills were related to performance in motor, linguistic and cognitive activities. Furthermore, Poloni et al. [79] reported that most LATAM countries did not have low-protein foods, including Phe-free amino acid fortified, and no alternative treatments available. Also, they found that low purchasing power, limited/insufficient availability of low-protein foods, poor adherence, and lack of technical resources to manage the diet were major barriers to treatment. And last, Martins et al. [66] reported that half of the parents and caregivers who completed the survey had financial burden related to PKU management, some had to stop working to care for the PKU patient, and others had to hire a caregiver to assist the PKU patient. With regards to patient's complaints, irritability was the most reported affected symtom accounting for $78 \%$ of the patients, followed by anxiety ( $67 \%)$, and lack of concentration (58\%). Despite these findings, $70 \%$ of the patients have never undergone a cognitive and/or executive function assessment, and limitation on social activities, impact on professional life, and the effect on self-esteem were also listed as barriers to receive appropriate assessments.

\section{Discussion}




\section{Main findings}

PKU is a genetic inborn error in the metabolism of Phe. The pathogenic variants that cause PKU are present in high frequency in some LATAM countries such as Brazil and Chile [107].

Based on pooled data from 21 case series and cross-sectional studies $[18,20-22,25,27,32,35,36,38$, $39,42,49,52-55,60,61,63,65,67,70-72,78,80,84,88,89,92,94,95,97,101,105]$ including 1,224 patients, we found evidence demonstrating the impact of PKU on affected individuals in LATAM, with pooled proportions of burden ranging from $9 \%$ with osteopenia to $53 \%$ with speech and language deficits. Furthermore, $53 \%$ of patients were not adherent to clinical recommendations and $37 \%$ experienced socioeconomic impact of PKU. These are higher rates as compared to what we were expecting given that there is the ability to effectively diagnose and treat PKU.

\section{Strengths and limitations}

Strengths of our review include a comprehensive search; assessment of eligibility, risk of bias and data abstraction independently and in duplicate; and an assessment of risk of bias that included a sensitivity analysis addressing homogeneity of study designs.

The primary limitation of our study is the highly heterogeneous nature of study samples in all studied clinical burden outcomes, except for the outcomes of obesity (Fig. 4, Panel A), osteopenia (Fig. 4, Panel C), and impact of PKU on caregiver health-related quality of life (Fig. 5, Panel B). Sources of this heterogeneity include both clinical and methodological diversities. The studies differed considerably in their mean age of patient selection, phenotype, modalities of implementation of the treatment (eg, newborn screening, access to treatment, lack of knowledgeable caregivers), and study designs (ie, case series and cross-sectional).

Furthermore, out of the 79 studies that met selection criteria, we were only able to include data in the meta-analysis from 21 of them (26.6\%). The majority of the studies provided data on only one prespecified outcome of interest, resulting in small sample sizes for many of the pooled analyses as well as there were studies that reported on late diagnosis patients and they were not included in the metaanalysis.

\section{Relation to prior research}

One systematic review [108] identified in the literature corroborates our findings showing that even with dietary treatment, long-term physical growth (ie, body weight, height/recumbent length, and body mass index) are not attained in PKU. Another systematic review [109] showed that bone mineral density was lower in PKU patients compared with a control group. With regards to the latter outcome, four studies [110-114] reported a prevalence of osteopenia and osteoporosis ranging from 5 to $14 \%$, which encompass our findings. Although we did not evaluate anthropometric variables in our review, we found a reasonable high prevalence of overweight individuals (11\%) and of obesity (12\%). 
Furthermore, a frequent prevalence of being overweight was described in another systematic review [115] ranging from 7.8 to $32.6 \%$ in children and adolescents with PKU, which is also consistent with our findings (23\%).

A very high prevalence of ADHD and hyperactivity (40\%) and a moderate rate of intellectual disability $(19 \%)$ were found in our review, which is consistent with others systematic reviews $[116,117]$ indicating that they are more common in both children and adults with PKU, despite being early diagnosed.

\section{Conclusions}

LATAM PKU patients presented with a high prevalence of clinical complications, regardless of whether there is the possibility of residual confounding due to publication bias and the high heterogeneity in the analysis. Although it is widely accepted that PKU treatment is needed for life, the current approach in LATAM is primarily by using dietary management, which does not seem sufficient to avoid the disease burden outcomes investigated in this research. Furthermore, this review showed that there is a high degree of poor adherence to clinical recommendations. This study also highlights the need to address well-conducted burden of illness studies in PKU patients in LATAM to further elucidate the full spectrum of complications seen in this disease, to inform the healthcare providers taking care of these patients as well as the public health authorities on the ongoing and significant complications of this genetic disorder.

\section{Abbreviations}

ADHD: Attention Deficit Hyperactivity Disorder; ACMG: American College of Medical Genetics and Genomics guidelines; HPA: hyperphenylalaninemia; LATAM: Latin American; PRISMA: Preferred Reporting Items for Systematic Review and Meta-Analysis; MOOSE: Meta-analysis of Observational Studies in Epidemiology; PAH: phenylalanine hydroxylase deficiency; PKU: Phenylketonuria; PROSPERO:

International Prospective Register of Systematic Reviews; MeSH: Medical Subject Headings; MEDLINE: Medical Literature Analysis and Retrieval System Online; EMBASE: Excerpta Medica Database; CENTRAL: Cochrane Central Register of Controlled Trials; LILACS: Latin American and Caribbean Health Sciences Literature; SciELO: Scientific Electronic Library Online; IBECS: Spanish Bibliographic Index of the Health Sciences: IBECS; BINACIS: National Bibliography in Health Sciences Argentina; MedCarib: Caribbean Health Sciences Literature; CUMED: National Medical Sciences Information Center of Cuba; BBO: Brazilian Bibliography of Dentistry; ANVISA: National Health Surveillance Agency; BDTD: Brazilian Digital Library of Theses and Dissertations; BMI: body mass index; JBI: Joanna Briggs Institute; Cl: Confidence Interval.

\section{Declarations}

\section{Ethics approval and consent to participate}

Not applicable. 


\section{Consent for publication}

Not applicable.

\section{Availability of data and materials}

All data generated or analysed during this study are included in this published article and its supplementary information files.

\section{Competing interests}

The other authors have declared no conflict of interests.

\section{Funding}

Funding to support this study and the preparation of this manuscript was provided by Biomarin Farmaceutica LTDA.

\section{Acknowledgements}

This manuscript was prepared according to the International Society for Medical Publication Professionals - Good Publication Practice for Communicating Company -Sponsored Medical Research: the GPP3 Guidelines.

\section{Funding}

Funding to support this study and the preparation of this manuscript was provided by BioMarin Farmacêutica LTDA.

\section{Authors' contributions}

All authors contributed to study design, interpretation, and analysis. ALSP, AMM, EMR, NS, AC, DV, EJ, DM, and IVDS were responsible for data identification, extraction, and synthesis. ALSP was responsible for creating the first draft and all authors read, revised, and approved the final manuscript.

\section{References}

1. Vockley J, Andersson HC, Antshel KM, Braverman NE, Burton BK, Frazier DM, et al. Phenylalanine hydroxylase deficiency: diagnosis and management guideline. Genet Med. 2014;16(2):188-200.

2. Borrajo JCG. Panorama epidemiológico de la fenilcetonuria (PKU) en Latinoamérica. Acta Pediatr Mex. 2012;33(6):279-87.

3. van Wegberg AMJ, MacDonald A, Ahring K, Belanger-Quintana A, Blau N, Bosch AM, et al. The complete European guidelines on phenylketonuria: diagnosis and treatment. Orphanet J Rare Dis. 2017;12(1):162. 
4. Williams RA, Mamotte CD, Burnett JR. Phenylketonuria: an inborn error of phenylalanine metabolism. Clin Biochem Rev. 2008;29(1):31-41.

5. Wang L, Zou H, Ye F, Wang K, Li X, Chen Z, et al. Household financial burden of phenylketonuria and its impact on treatment in China: a cross-sectional study. J Inherit Metab Dis. 2017;40(3):369-76.

6. Moher D, Liberati A, Tetzlaff J, Altman DG, Group P. Preferred reporting items for systematic reviews and meta-analyses: the PRISMA statement. BMJ. 2009;339:b2535.

7. Stroup DF, Berlin JA, Morton SC, Olkin I, Williamson GD, Rennie D, et al. Meta-analysis of observational studies in epidemiology: a proposal for reporting. Meta-analysis Of Observational Studies in Epidemiology (MOOSE) group. JAMA. 2000;283(15):2008-12.

8. van Spronsen FJ, van Wegberg AM, Ahring K, Bélanger-Quintana A, Blau N, Bosch AM, et al. Key European guidelines for the diagnosis and management of patients with phenylketonuria. Lancet Diabetes Endocrinol. 2017;5(9):743-56.

9. Downes MJ, Brennan ML, Williams HC, Dean RS. Development of a critical appraisal tool to assess the quality of cross-sectional studies (AXIS). BMJ Open. 2016;6(12):e011458.

10. Gagnier JJ, Kienle G, Altman DG, Moher D, Sox H, Riley D, et al. The CARE guidelines: consensusbased clinical case report guideline development. J Clin Epidemiol. 2014;67(1):46-51.

11. Guyatt GH, Busse JW. Modification of Ottawa-Newcastle to assess risk of bias in nonrandomized trials [Available from: http://distillercer.com/resources/].

12. El Dib R, Touma NJ, Kapoor A. Cryoablation vs radiofrequency ablation for the treatment of renal cell carcinoma: a meta-analysis of case series studies. BJU Int. 2012;110(4):510-6.

13. El Dib R, Nascimento Junior P, Kapoor A. An alternative approach to deal with the absence of clinical trials: a proportional meta-analysis of case series studies. Acta Cir Bras. 2013;28(12):870-6.

14. DerSimonian R, Laird N. Meta-analysis in clinical trials. Control Clin Trials. 1986;7(3):177-88.

15. Higgins JP, Thompson SG, Deeks JJ, Altman DG. Measuring inconsistency in meta-analyses. BMJ. 2003;327(7414):557-60.

16. The Nordic Cochrane Centre TCC. Review Manager (RevMan). 5.3. Copenhagen: The Nordic Cochrane Centre, The Cochrane Collaboration; 2011.

17. Amorim T, Boa-Sorte N, Leite MEQ, Acosta AX. Aspectos clínicos e demográficos da fenilcetonúria no Estado da Bahia. Revista Paulista de Pediatria. 2011;29:612-7.

18. Andere J, Mota de Avelar-Alchorne M, Schmidt BJ, Schwery-Michalany N. [Classic phenylketonuria: dermatological and histopathological aspects in 35 patients]. Bol Med Hosp Infant Mex. 1988;45(2):73-8.

19. Azcoiti ME, Chiesa A, Valle RE, Mendez G, Gotta V G, et al. Implementation of molecular diagnosis for PAH related disorders in a public hospital. Annual Meeting of Bioscience Societes 2020; 10-13 November 2020. MEDICINA2020.

20. Beckhauser MT, Beghini Mendes Vieira M, Moehlecke Iser B, Rozone DELG, Rodrigues Masruha M, Lin J, et al. Attention Deficit Disorder with Hyperactivity Symptoms in Early-Treated Phenylketonuria 
Patients. Iran J Child Neurol. 2020;14(1):93-103.

21. Benítez V, San Julián E, Rodríguez MM. Fenilcetonuria: A propósito de dos pacientes. Arch Pediatr Urug. 2001;72:293-7.

22. Bernal AC, Eiroa H. Fenilcetonuria de diagnostico tardio. Sociedad Iberoamericana de Información Científica (SIIC). 2017.

23. Blanco FA, Quintana AB, Martinez CV, Pardo MM. [Importance of early diagnosis of phenylketonuria in women and control of phenylalanine levels during pregnancy]. Nutr Hosp. 2012;27(5):1658-61.

24. Brandalize SRC. Avaliação dos resultados do programa de prevenção e promoção da saúde de fenilcetonúricos do estado do Paraná: condição motora dos portadores de fenilcetonúria com diagnóstico precoce. Universidade Estadual de Ponta Grossa - PR; 2002.

25. Brandalize SRC, Czeresnia D. Avaliação do programa de prevenção e promoção da saúde de fenilcetonúricos. Rev Saúde Pública. 2004;38:300-6.

26. Camatta GC. Influência do consumo proteico, da prática de atividade física, do controle metabólico, do estágio de maturação sexual e do IMC no percentual de gordura corporal de adolescentes fenilcetonúricos. Universidade Federal de Minas Gerais - Belo Horizonte; 2017.

27. Camatta GC, Kanufre VC, Alves MRA, Soares RDL, Norton RC, de Aguiar MJB, et al. Body fat percentage in adolescents with phenylketonuria and associated factors. Mol Genet Metab Rep. 2020;23:100595.

28. Pardo-Campos ML, Enacan R, Valle MG, Chiesa A. Parenting Styles and Coping Strategies in PKU Early Detected Children. J Inborn Errors Metab Screen. 2021;9.

29. Pardo-Campos ML, Enacan R, Valle MG, Chiesa A. Parenting styles and coping strategies in PKU children 11th Congress of the Latin American Society of Inborn Errors of Metabolism and Neonatal Screening; 12-15 May 2019; Buenos Aires: J Inborn Errors Metab Screen; 2019.

30. Pardo-Campos ML, Enacan R, Valle MG, Chiesa A. Cognitive asssessment of early detected and treated PKU children. 11th Congress of the Latin American Society of Inborn Errors of Metabolism and Neonatal Screening; 12-15 May 2019; Buenos Aires: J Inborn Errors Metab Screen; 2019.

31. Castro IPS. Avaliação da inteligência de pacientes com fenilcetonúria atendidos pelo programa de triagem neonatal de Minas Gerais. Universidade Federal de Minas Gerais - Belo Horizonte; 2008.

32. Castro IPS, Borges JM, Chagas HA, Tiburcio J, Starling AL, Aguiar MJ. Relationships between phenylalanine levels, intelligence and socioeconomic status of patients with phenylketonuria. $J$ Pediatr. 2012;88(4):353-6.

33. Cerqueira MMM. O engajamento dos cuidadores na dieta para as suas crianças fenilcetonúricas: influência de fatores sócio-demográficos e psicossociais. Universidade Federal de Minas Gerais Belo Horizonte; 2004.

34. Chiesa A, Fraga C, Prieto L, Pardo ML. Modelo de atención de pacientes con fenilcetonuria (PKU) en Argentina. Acta Pediátrica de México. 2012;33(6):308-10. 
35. Colombo MC, Troncoso L, Raimann E, Perates CG, Barros T, Cornejo V. Diagnostico de fenilquetonuria en Chile. Rev Chil Pediatr. 1988;59(4):235-9.

36. Cornejo EV, Castro G, Fernández E, Cabello JF, Raimann E, De la Parra APS, et al. Modelo chileno de seguimiento a largo plazo para fenilcetonuria (PKU). Acta Pediatr Mex. 2012;33(6):301-7.

37. Cornejo EV, Concha M, Cabello JF, Raimann E. [Lipids composition diet in phenylketonuric children with early diagnosis]. Arch Latinoam Nutr. 2005;55(4):332-5.

38. Cornejo EV, Manríquez EV, Colombo CM, Mabe SP, Jiménez MM, De la Parra CA, et al. Fenilquetonuria de diagnóstico neonatal y lactancia materna. Rev Med Chile. 2003;131:1280-7.

39. Cornejo EV, Raimann BE, Godoy PX, Colombo CM. Seguimiento de pacientes con hiperfenilalaninemia diagnosticados precozmente. Rev Chil Pediatr. 1995;66:300-3.

40. da Silva FGS, FP EV, de Souza CFM, Schwartz IVD. Attention-deficit hyperactivity disorder in Brazilian patients with phenylketonuria. Acta Neurol Belg. 2020;120(4):893-9.

41. De Lucca M, Barba-Guzmán C, Cobo-Sevilla V, Latta MA. Fenilcetonuria de diagnóstico tardío y mutaciones asociadas en una familia ecuatoriana. Invest Clin. 2017;58:274-83.

42. Diament AJ, Lefèvre AB. Fenilcetonúria: estudo clínico e mediante biópsia cerebral. Arq Neuropsiquiatr. 1967;25:1-16.

43. Dutra VF. Avaliação neuropsicológica de crianças e adolescentes com hiperfenilalaninemias. Faculdade de Ciências Médicas da Universidade de Campinas - Campinas; 2013.

44. Enacán R, Prieto L, Nuñez-Miñana M, Fernandez L, Valle MG, Salerno M, et al. Phenylalanine hydroxilase (PAH) genotyping in PKU argentine patients. Congreso Latinoamericano de Erroes Innatos del Metabolismo y Pesquisa Neonatal; 12-15 May 2019; Buenos Aires. J Inborn Errors Metab Screen. 2019a.

45. Enacán R, Miñana MN, Fernandez L, Valle MG, Salerno M, Fraga $\mathrm{Cl}$, et al. Phenylalanine Hydroxylase (PAH) Genotyping in PKU Argentine Patients. J J Inborn Errors Metab Screen. 2019b;7..

46. Escaf M. Fenilcetonuria e hiperfenilalaninemia en recién nacidos. Salud Uninorte. 2003(17):36-9.

47. Esteves MTC, Chagas ACR, Vignoli VV, Castilho OB. Incidência de fenilcetonúria em pacientes com retardamento mental em Alfenas - MG. Rev Esc Farm Odontol Alfenas. 1990(12):99-107.

48. Fagioli D, Coelho HDS, Maturana N, Almeida EC, Marques T, Masson IB. Práticas alimentares nos primeiros seis meses de vida de crianças com Fenilcetonúria. J Health Sci Inst. 2014;32(1):70-3.

49. Figueira VB. Perfil clínico e epidemiológico de pacientes portadores de fenilcetonúria no estado de Goiás. Universidade Federal de Goiás - Goiânia; 2018.

50. Figueiró-Filho EA, Lopes AHA, Senefonte FRA, Júnior VGS, Botelho CA, Duarte G. [Maternal phenylketonuria: a case report]. Rev Bras Ginecol Obstet. 2004;26(10):813-7.

51. Fisberg RM, Silva-Fernandes ME, Schmidt BJ, Fisberg M. Nutritional evaluation of children with phenylketonuria. Sao Paulo Med J. 1999;117:185-91.

52. Gejão MG, Ferreira AT, Silva GK, Anastácio-Pessan FL, Lamônica DAC. Communicative and psycholinguistic abilities in children with phenylketonuria and congenital hypothyroidism. J Appl 
Oral Sci. 2009;17:69-75.

53. Gelvez N, Acosta J, Lopez G, Castro D, Prieto JC, Bermudez M, et al. [Phenotypic and molecular characterization of a Colombian family with phenylketonuria]. Biomedica: Revista del Instituto Nacional de Salud. 2016;36(3):390-6.

54. Jiménez-Pérez MO, Gómez-Garza G, Ruiz-García M, Fernández-Lainez C, Ibarra-González I, VelaAmieva M. Resonancia magnética nuclear de encéfalo en pacientes con fenilcetonuria diagnosticada tardíamente. Acta Pediatr de Mex. 2015;36:09-17.

55. Kanufre VC, Soares RDL, Alves MRA, Aguiar MJB, Starling ALP, Norton RC. Metabolic syndrome in children and adolescents with phenylketonuria. J Pediat. 2015;91:98-103.

56. Kanufre VC, Starling AL, Leao E, Aguiar MJ, Santos JS, Soares RD, et al. Breastfeeding in the treatment of children with phenylketonuria. J Pediat. 2007;83(5):447-52.

57. Keselman A, Cassinelli H, Fraga C, Gruñeiro-Papendieck L, Chiesa A. Bone mineral density (BMD) and phenylketonuria (PKU). 7th Joint Meeting Paediatric Endocrinology in collaboration with APEG, APPES, JSPE and SLEP; Lyon, France 2005.

58. Fraga C, Valle MG, Enacan R, Chiesa A. Bone Mineral Density and BH4 Treatment. 13th International Congress of Inborn Errors of Metabolism. Brazil: J Inborn Errors Metab Screen; 2017. pp. 1-413. 5-8 September 2017; Rio de Janeiro,.

59. Lamônica DAC, Stump MV, Pedro KP, Rolim-Liporacci MC, Caldeira ACGC, Anastácio-Pessan FL, et al. Acompanhamento do aleitamento materno no tratamento de crianças com fenilcetonúria. J Soc Bras Fonoaudiol. 2012;24(4):3816-9.

60. Lamônica DAC, Gejão MG, Anastácio-Pessan FL. Fenilcetonúria e habilidades de leitura e escrita. Revista CEFAC. 2015;17:143-50.

61. Mahfoud A, de Lucca M, Domínguez CL, Arias I, Casique L, Araujo K, et al. [Clinical findings and mutational spectrum in Venezuelan patients with delayed diagnosis of phenylketonuria]. Rev Neurol. 2008;47(1):5-10.

62. Malloy-Diniz LF, Cardoso-Martins C, Carneiro KC, Cerqueira MMM, Ferreira APA, Aguiar MJB, et al. Funções executivas em crianças fenilcetonúricas: variações em relação ao nível de fenilalanina. Arq Neuropsiquiatr. 2004;62:473-9.

63. Mancini PC, Starling ALP, Penna LM, Ramos CAV, Ferreira MIO, lório MCM. Achados audiológicos em crianças com fenilcetonúria. Revi Soc Bras Fonoaudiol. 2010;15:383-9.

64. Mariño M, Zarzalejo Z. Tratamiento nutricional de um niño com fenilcetonuria de diagnóstico neo natal. Estudio de caso. An Venez Nutr. 2000;13(1):202-9.

65. Martins FF. Efeito do consumo de biscoitos enriquecidos com cálcio em pacientes com fenilcetonúria. Universidade Federal Fluminense - Niterói; 2007.

66. Martins AM, Pessoa ALS, Quesada AA, Ribeiro EM. Unmet needs in PKU and the disease impact on the day-to-day lives in Brazil: Results from a survey with 228 patients and their caregivers. Mol Genet Metab Rep. 2020;24:100624. 
67. Mendes AB. Fragilidade Óssea dos Fenilcetonúricos, Reflexo da Dietoterapia? - Um estudo com pacientes da APAE-RIO. Revista de Pediatria SOPERJ. 2006;7(2):20.

68. Menezes RSB, Ribeiro EM, Coelho FMS, Nogueira HBR. Fenilcetonúria associada à alergia à proteína do leite de vaca. J Health Biol Sci. 2019;7(1):97-100.

69. Monteiro LTB, Cândido LMB. Fenilcetonúria no Brasil: evolução e casos. Revista de Nutrição. 2006;19:381-7.

70. Morão CPAB. Perfil neuropsicológico e desempenho executivo de crianças com fenilcetonúria tratada. Universidade Presbiteriana Mackenzie; 2017.

71. Nalin T, Perry IDS, Refosco LF, Netto CBO, Souza CFM. Fenilcetonúria no sistema único de saúde: avaliação de adesão ao tratamento em um centro de atendimento do Rio Grande do Sul. Rev HCPA. 2010;30(3):225-32.

72. Neto EV, Filho HSM, Monteiro CB, Carvalho LM, Tonon T, Vanz AP, et al. Quality of life and adherence to treatment in early-treated Brazilian phenylketonuria pediatric patients. Braz J Med Biol Res. 2018;51.

73. Oliveira RF. Condiçöes de saúde dental e gengival em crianças com fenilcetonúria atendidas na Fundaçäo Ecumênica de Proteçäo ao Excepcional (FEPE) no Estado do Paraná 2001.

74. Paneque OA, Chacón GG, Galcerán TZ, Peña DYV, Ramírez RM, Roca TZO. Evaluación del estado de salud en pacientes con fenilcetonúria. Rev Cubana Pediatr. 2013;85(3):320-9.

75. Patricio YP, Maritza M. Fenilcetonuria em um neonato de 29 semanas de edad gestacional: reporte de caso clinico. Rev Ecuat Pediatr. 2018;19(1):16-7.

76. Pereda-Torales L, Calcáneo-García JA, Enríquez-Torrecilla R, Badillo-Báez EM, Soler-Huerta E. Identificación de un caso de fenilcetonuria a través del tamizaje neonatal. Bol Med Hosp Infant Mex. 2008;65:290-6.

77. Peredo OP, Raimann BE, Cataldo GX, Gallardo GS, Cornejo EV. Sindrome de fenilquetonuria materna, un nuevo desafío para Chile. Rev Chil Nutr. 2010;37:111-7.

78. Pérsico RS, Nalin T, R LF, Vairo FP, Souza CFM. Análise da densidade mineral óssea em pacientes com fenilcetonúria e sua correlação com parâmetros nutricionais. Clin Biomed Res. 2019;39(1):2431.

79. Poloni S, Dos Santos BB, Chiesa A, Specola N, Pereyra M, Saborio-Rocafort M, et al. Current Practices and Challenges in the Diagnosis and Management of PKU in Latin America: A Multicenter Survey. Nutrients. 2021;13(8).

80. Queiroz IRG, Pondé MP. Percepção de pais/cuidados de indivíduos com fenilcetonúria, com e sem autismo, acompanhados em serviço de referência em triagem neonatal. Rev Psicol Divers Saúde. 2015;4(1):87-95.

81. Rasner M, Vomero A, Varacchi C, Peluffo G, Giachetto G, Kanopa V. Fenilcetonuria: Descripción de un caso clínico. Arch Pediatr Urug. 2014;85:28-33. 
82. Ribeiro PS, Torres TL, Starling ALP, lório MCM, Mancini PC. Crianças com fenilcetonúria: avaliação audiológica básica e supressão das otoemissões. Rev Soc Bras Fonoaudiol. 2012;17:248-53.

83. Russo-Estavillo C, Vásquez-Avelar S, G-O JE, Real-Guerrero J, Belmont-Martínez L, Escoto-Delgadillo $M$, et al. High Frequency of Severe Phenylketonuria in Jalisco, Mexico. Int J Genet. 2018;18(1):1-6.

84. Sánchez-Peña A, Martínez-de Villarreal L, Arteaga-Alcaraz G, Torres-Sepúlveda R, MarroquínEscamilla AR, Abrego-Moya V, et al. Secuelas neurológicas en tres pacientes con fenilcetonuria clásica diagnosticada tardíamente. Bol Med Hosp Infant Mex. 2008;65:191-5.

85. Santos JS, Aguiar MJB, Starling ALP, Kanufre VC, Tibúrcioz JD, Lima MOB. Consumo alimentar de lactentes com fenilcetonúria em uso de aleitamento materno. Rev de Nutr. 2011;24:863-72.

86. Santos MP, Haack A. Fenilcetonúria em escolar: um relato de caso. Com Ciências Saúde. 2013;24(2):187-200.

87. Schmidt DE, Norton RC, Starling ALP, Rodrigues VM, Aguiar MJB, Kanufre VC, et al. Deficiência de vitamina B12 e fenilcetonúria. Rev Med Minas Gerais. 2016;26(Supl 2)):31-S4.

88. Sena BS. Estado nutricional e indicadores antropométricos de risco cardiovascular de pacientes com diagnótico de fenilcetonúria atendidos em um serviço de referência do nordeste brasileiro. Universidade Federal de Pernambuco - Vitória de Santo Antão; 2018.

89. Silva FGS. Prevalência de transtorno de déficit de atenção e hiperatividade e outras alterações neurológicas em fenilcetonúricos de um centro do sul do país. Universidade Federal do Rio Grande do Sul - Porto Alegre; 2018.

90. Silva FGS, FP EV, de Souza CFM, Schwartz IVD. Attention-deficit hyperactivity disorder in Brazilian patients with phenylketonuria. Acta Neurol Belg. 2020;120(4):893-9.

91. Silva GK. Habilidades do comportamento comunicativo de crianças com fenilcetonúria tratadas desde o período neonatal. Faculdade de Odontologia de Bauru da Universidade de São Paulo Bauru; 2008.

92. Silva GK, Lamônica DAC. Desempenho de crianças com fenilcetonúria no Teste de Screening de Desenvolvimento Denver - II. Pro-Fono. 2010;22:345-50.

93. Silva LF. Avaliação dos níveis de marcadores de neurodegeneração em plasma de pacientes fenilcetonúricos. Universidade do Extremo Sul Catarinense - Criciúma; 2016a.

94. Silva LF, Rodrigues GRB, Cavalcante RH, Silva JAC. Fenilcetonúria: perfil e abandono de tratamento em centro de referência no Pará. Rev Soc Bras Clin Med. 2016b;14(1):13-7.

95. Silveira AM, Lima PL, Alves MRA, Soares RDL, Kanufre VC, Rodrigues VM, et al. Overweight/obesity in adolescents with phenylketonuria: Protective and predisposing factors. J Pediatr. 2021.

96. Starling ALP. Densitometria óssea em crianças e adolescentes fenilcetonúricos. Universidade Federal de Minas Gerais - Belo Horizonte; 2005.

97. Steiner CE, Acosta AX, Guerreiro MM, Marques-de-Faria AP. Genotype and natural history in unrelated individuals with phenylketonuria and autistic behavior. Arq Neuropsiquiatr. 2007;65(2A):202-5. 
98. Stranieri I, Takano OA. Avaliação do Serviço de Referência em Triagem Neonatal para hipotireoidismo congênito e fenilcetonúria no Estado de Mato Grosso, Brasil. Arq Bras Endocrinol Metabol. 2009;53:446-52.

99. Tanaka NYY, Turcato MF, Nicoletti CF, Nonino CB, Martins LD, lannetta O, et al. Effects of Short-Term Calcium Supplementation in Children and Adolescents with Phenylketonuria. J Clin Densitom. 2018;21(1):48-53.

100. Teruya KI. Fatores percebidos pelos pacientes como barreiras a adesão ao tratamento de fenilcetonúria no Brasil. Universidade Federal do Rio Grande do Sul - Porto Alegre; 2019.

101. Teruya KI, Remor E, Schwartz IVD. Development of an inventory to assess perceived barriers related to PKU treatment. J Patient Rep Outcomes. 2020;4(1):29.

102. Tonon T, Martinez C, Poloni S, Nalin T, MacDonald A, Schwartz IVD. Food Neophobia in Patients With Phenylketonuria. J Endocrino Metab. 2019;9(4):108-12.

103. Urbanes MB, Alvear C, Moreniz C, Alayon AN, Suárez A. Epileptic encephalopathy by phenylcetonuria. Acta Neurol Colomb. 2006;22:316-22.

104. Valle MG, Enacan R, Mendez V, Prieto L, Pardo-Campos ML, Chiesa A. PKU Clinical Experience. 11th Congress of the Latin American Society of Inborn Errors of Metabolism and Neonatal Screening; 1215 May 2019; Buenos Aires, Argentina: J Inborn Errors Metab Screen; 2019.

105. Vieira TA. Fatores associados a adesão ao tratamento dos pacientes com fenilcetonúria acompanhados pelo serviço de genética médica do hospital de clínicas de Porto Alegre. Universidade Federal do Rio Grande do Sul - Porto Alegre; 2010.

106. Vieira TA, Nalin T, Krug BC, Bittar CM, Oliveira Netto CB, Schwartz IVD. Adherence to Treatment of Phenylketonuria: A Study in Southern Brazilian Patients. J Inborn Errors Metab Screen. 2015;3.

107. Desviat LR, Pérez B, De Lucca M, Cornejo V, Schmidt B, Ugarte M. Evidence in Latin America of recurrence of V388M, a phenylketonuria mutation with high in vitro residual activity. Am J Med Genet A. 1995;57(2):337-42.

108. Ilgaz F, Pinto A, Gokmen-Ozel H, Rocha JC, van Dam E, Ahring K, et al. Long-Term Growth in Phenylketonuria: A Systematic Review and Meta-Analysis. Nutrients. 2019;11(9).

109. de Castro MJ, de Lamas C, Sanchez-Pintos P, Gonzalez-Lamuno D, Couce ML. Bone Status in Patients with Phenylketonuria: A Systematic Review. Nutrients. 2020;12(7).

110. Lage S, Bueno M, Andrade F, Prieto JA, Delgado $C$, Legarda $M$, et al. Fatty acid profile in patients with phenylketonuria and its relationship with bone mineral density. J Inherit Metab Dis. 2010;33(Suppl 3):363-71.

111. Zeman J, Bayer M, Stepán J. Bone mineral density in patients with phenylketonuria. Acta Paediatr. 1999;88(12):1348-51.

112. Mendes AB, Martins FF, Cruz WM, da Silva LE, Abadesso CB, Boaventura GT. Bone development in children and adolescents with PKU. J Inherit Metab Dis. 2012;35(3):425-30. 
113. Modan-Moses D, Vered I, Schwartz G, Anikster Y, Abraham S, Segev R, et al. Peak bone mass in patients with phenylketonuria. J Inherit Metab Dis. 2007;30(2):202-8.

114. Coakley KE, Douglas TD, Singh RH. Using predictive modeling to estimate bone mineral density in children and adults with phenylketonuria. Interdisciplinary symposium on osteoporosis 2013 Patient-centered care: Developing successful bone health teams, ISO 2013 Chicago, IL United States. 2013. p. S431-S2.

115. Sena BDS, Andrade MIS, Silva A, Dourado KF, Silva ALF. Overweight and Associated Factors in Children and Adolescents with Phenylketonuria: A Systematic Review. Rev Paul Pediatr. 2020;38:e2018201.

116. Bilder DA, Noel JK, Baker ER, Irish W, Chen Y, Merilainen MJ, et al. Systematic Review and MetaAnalysis of Neuropsychiatric Symptoms and Executive Functioning in Adults With Phenylketonuria. Dev Neuropsychol. 2016;41(4):245-60.

117. Burlina AP, Lachmann RH, Manara R, Cazzorla C, Celato A, van Spronsen FJ, et al. The neurological and psychological phenotype of adult patients with early-treated phenylketonuria: A systematic review. J Inherit Metab Dis. 2019;42(2):209-19.

\section{Tables}

Table 1 is available in the Supplemental Files section.

\section{Figures}




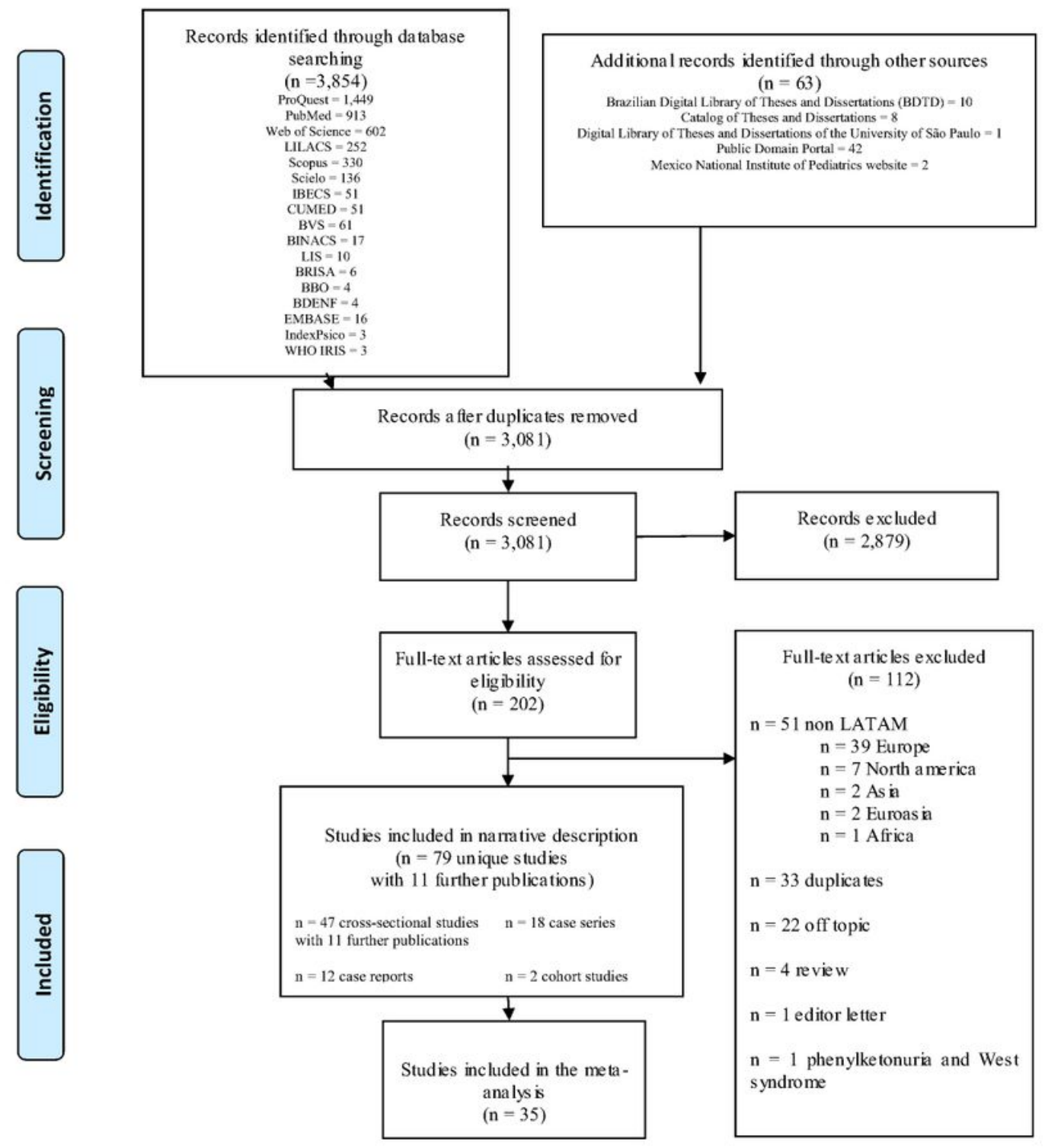

Figure 1

PRISMA flow diagram. 

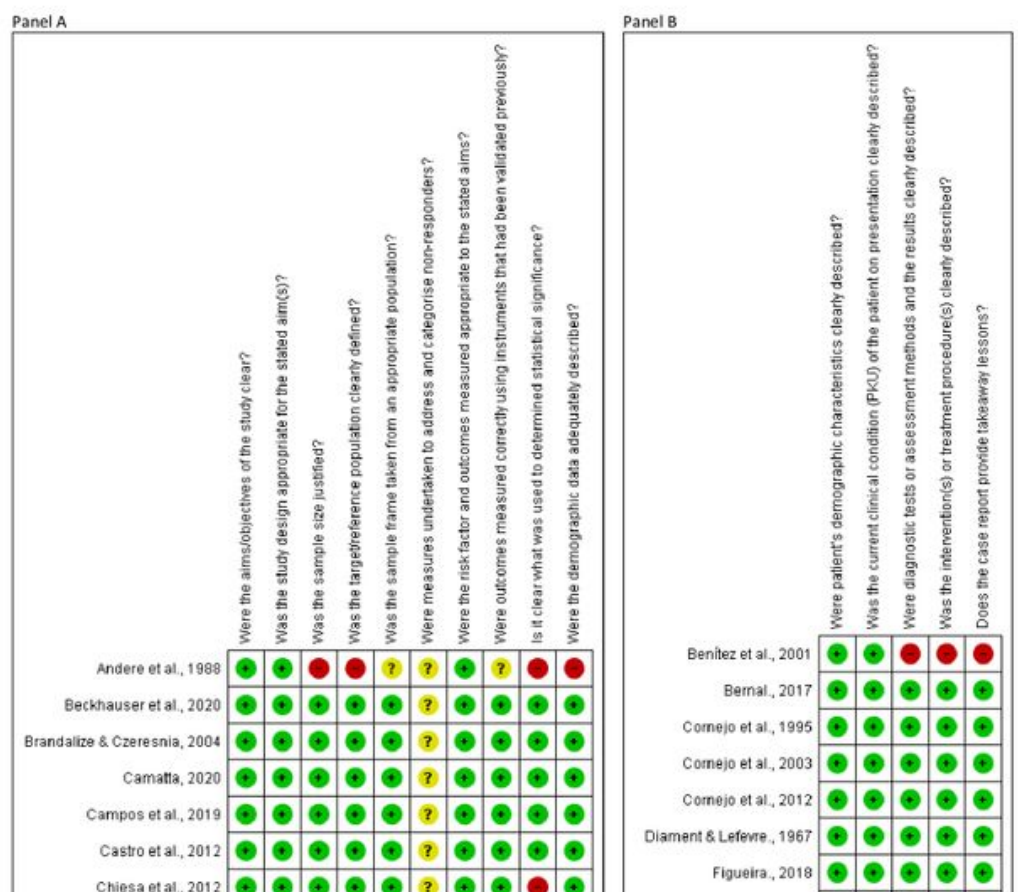

Figure 2

Risk of bias assessment. Panel A: cross-sectional studies. Panel B: case series studies. 


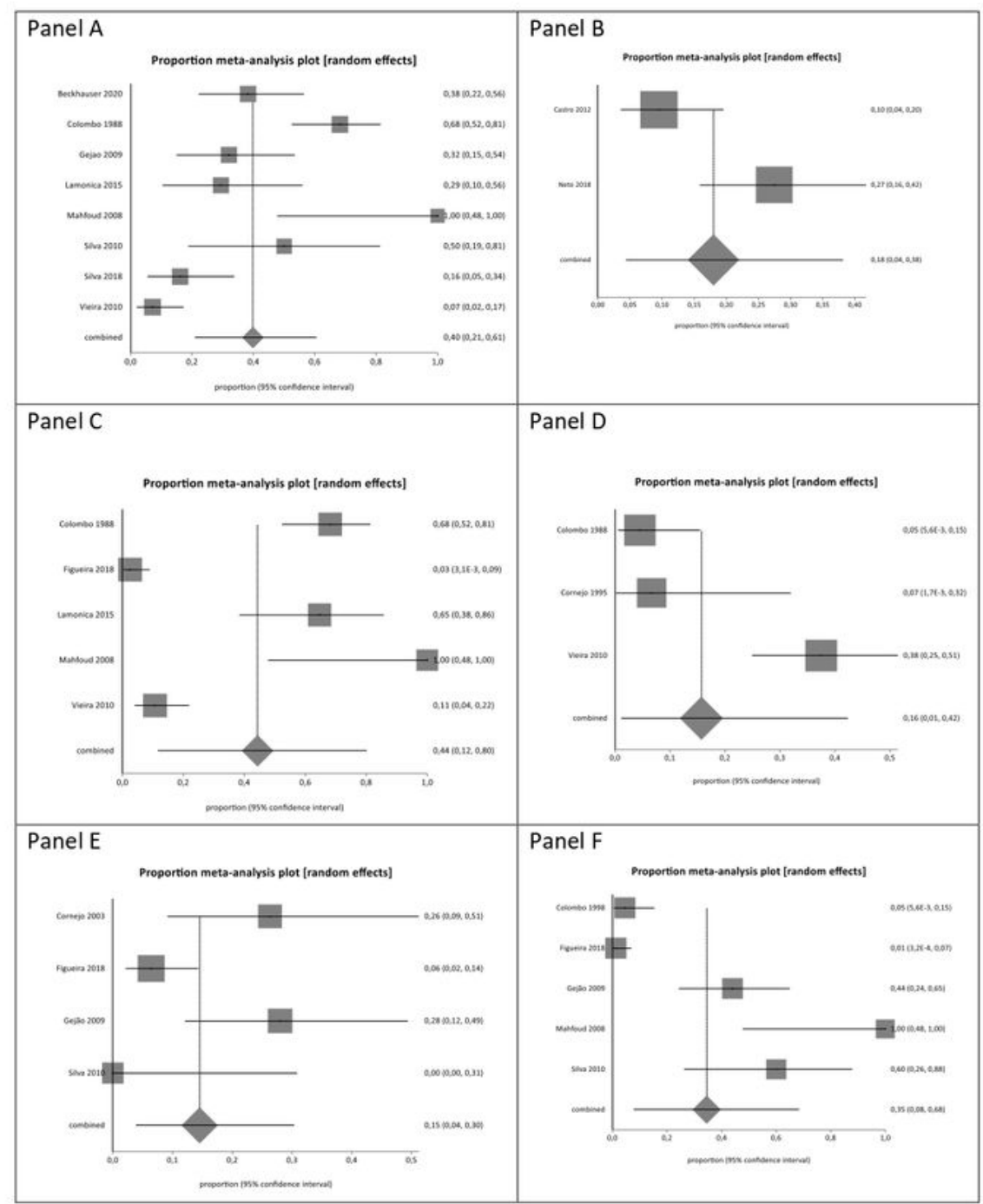

Figure 3

Proportional meta-analysis of neurological, neurocognitive, and neuropsychiatric impairments outcomes in early-diagnosed PKU patients. Panel A: ADHD and hyperactivity. Panel B: Intellectual disability. Panel C: Irritability and aggressiveness. Panel D: Mental disorders. Panel E: Motor delay. Panel F: Speech and language deficits. 


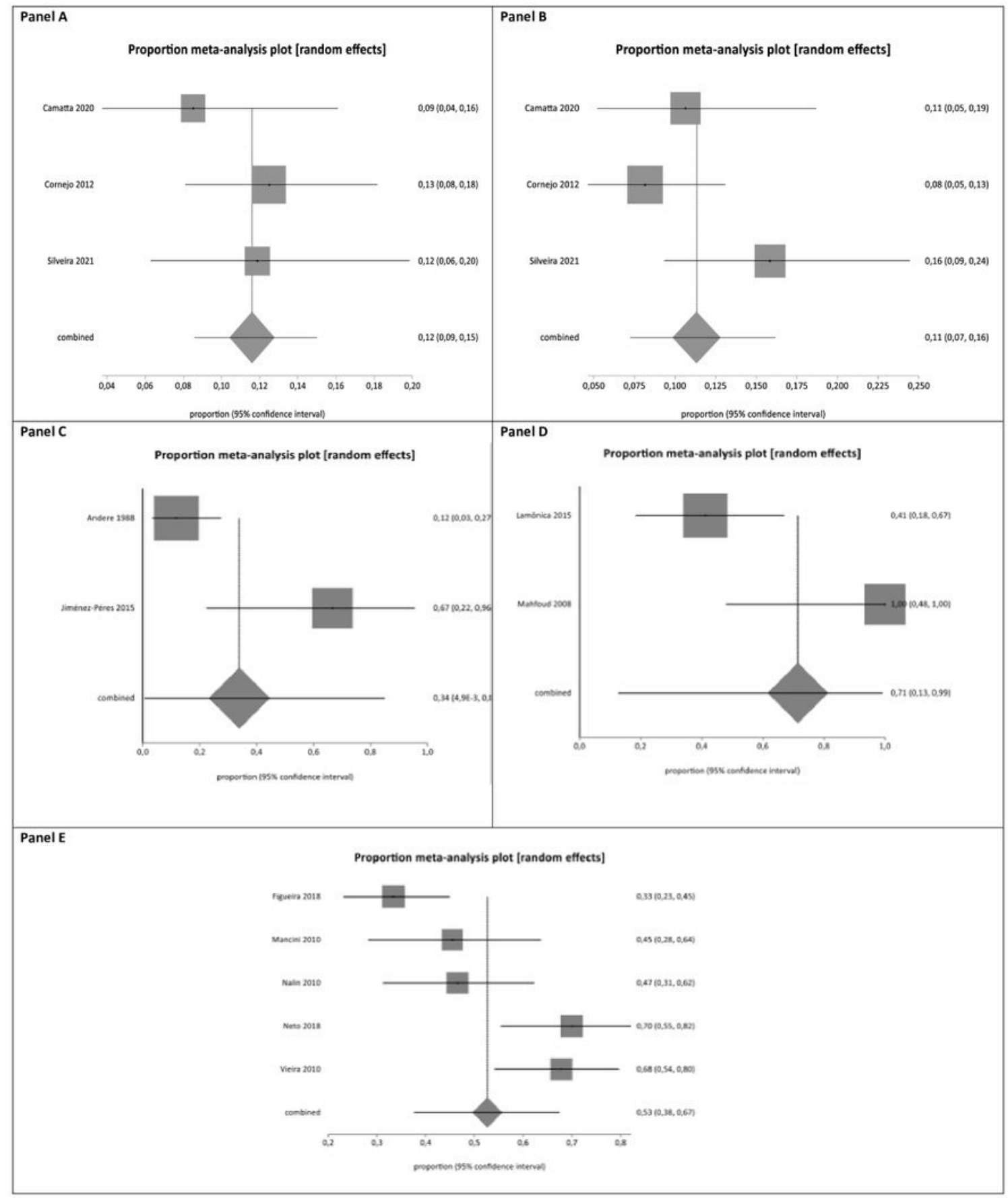

Figure 4

Proportional meta-analysis of other outcomes in early-diagnosed PKU patients. Panel A: Obese. Panel B: Overweight. Panel C: Skin alterations. Panel D: Sleeping disorders. Panel E: Patient adherence to clinical recommendations. 


\section{Proportion meta-analysis plot [random effects]}

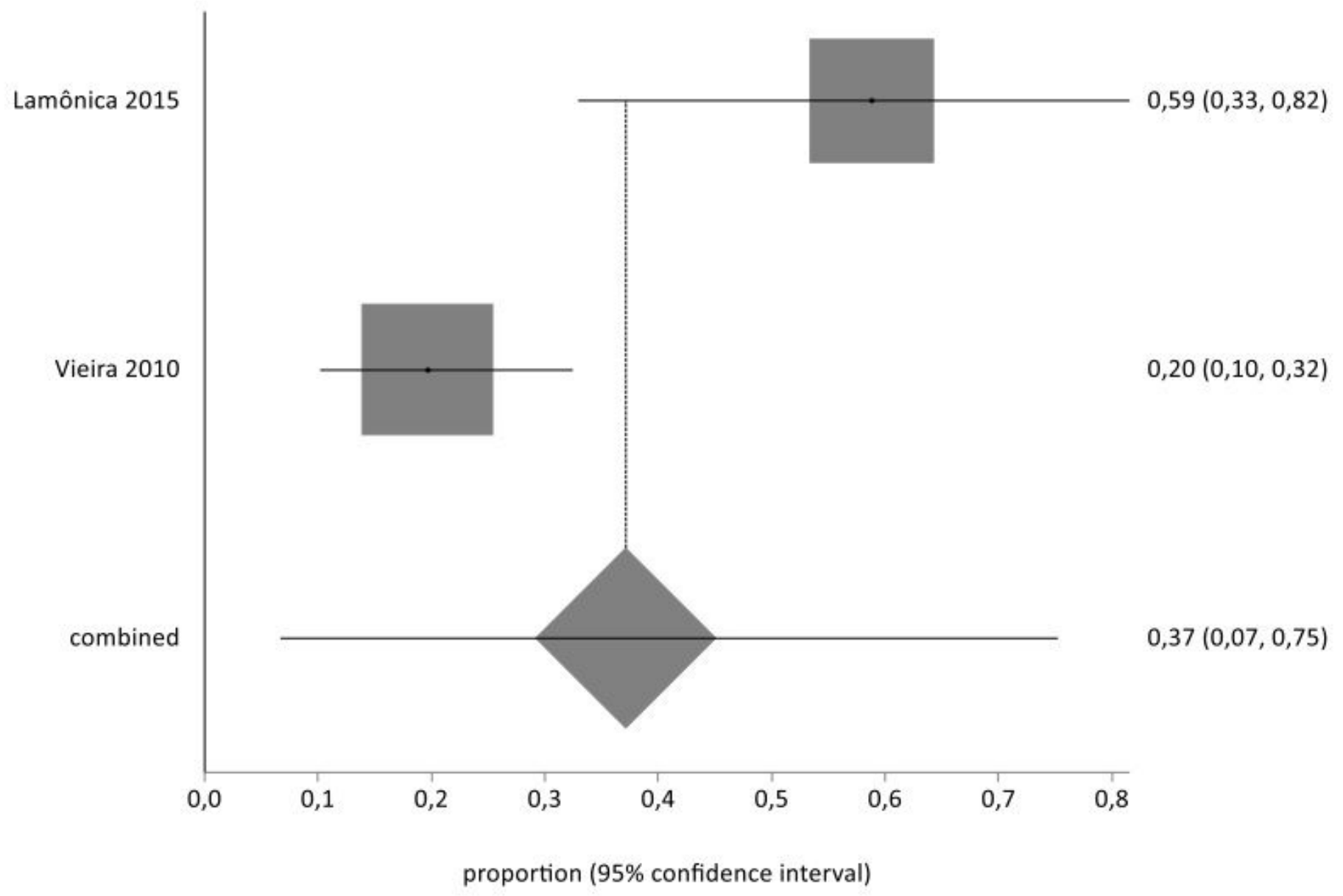

\section{Figure 5}

Proportional meta-analysis of economic outcomes in early-diagnosed PKU patients.

\section{Supplementary Files}

This is a list of supplementary files associated with this preprint. Click to download.

- Table1.docx

- Supplementarytable1.Searchstrategy.docx

- Supplementarytable2.Studiesevaluatingotheroutcomes.docx

- Supplementarytable3.Outcomesoncasereportsstudies.docx 
- Supplementarytable4.RoBforcrosssectionalstudies.docx

- Supplementarytable5.RoBforcaseseries.docx 